\title{
Clinical assessment and pathophysiology of Bothrops venom-related acute kidney injury: a scoping review
}

\author{
Polianna Lemos Moura Moreira Albuquerque ${ }^{1,2}$ (D), José Hicaro Hellano Gonçalves Lima Paiva ${ }^{3}$ (D), \\ Alice Maria Costa Martins ${ }^{4}$, Gdayllon Cavalcante Meneses ${ }^{4}$ (D), Geraldo Bezerra da Silva Júnior ${ }^{5}$ (D), \\ Nicholas Buckley ${ }^{6}$ (D), Elizabeth De Francesco Daher ${ }^{7}$ (D) \\ ${ }^{1}$ University of Fortaleza (Unifor), Fortaleza, Ceará, Brazil. \\ ${ }^{2}$ Toxicological Information and Assistance Center, Instituto Doutor Jose Frota Hospital, Fortaleza, Ceará, Brazil. \\ ${ }^{3}$ State University of Ceará (UECE), Fortaleza, Ceará, Brazil. \\ ${ }^{4}$ Graduate Program in Pharmaceutical Sciences, Federal University of Ceará (UFC), Fortaleza, Ceará, Brazil. \\ ${ }^{5}$ Public Health and Medical Sciences Graduate Programs, School of Medicine, University of Fortaleza, Fortaleza, Ceará, Brazil. \\ ${ }^{6}$ The University of Sydney, Sydney, New South Wales, Australia. \\ ${ }^{7}$ Graduate Program in Medical Sciences, Federal University of Ceará (UFC), Fortaleza, Ceará, Brazil.
}

\section{Keywords:}

Bothrops

Snakebite

Acute kidney injury (AKI)

Envenoming

\begin{abstract}
Bothrops are one of the most common medically important snakes found in Latin America. Its venom is predominantly hemotoxic and proteolytic, which means that local lesion (edema and redness) and hemorrhagic symptoms are recurrent in envenoming by this snake. Although hemorrhage is usually the major cause of death, snakebite-related acute kidney injury is another potentially fatal clinical complication that may lead to chronic kidney disease. The present review highlights the main studies on Bothrops venom-related acute kidney injury, including observational, cross-sectional, case-control and cohort human studies available up to December 2019. The following descriptors were used according to Medical Subject Headings (MeSH): on Medline/Pubmed and Google Scholar "acute kidney injury" or "kidney disease" and "Bothrops"; on Lilacs and SciELO "kidney disease" or "acute kidney injury" and "Bothrops". Newcastle-Ottawa quality assessment scale was used to appraise the quality of the cross-sectional and cohort studies included. The selection of more severe patients who looked for health care units and tertiary centers is a risk of bias. Due to the methodological heterogeneity of the studies, a critical analysis of the results was performed based on the hypothesis that the design of the included studies influences the incidence of acute kidney injury. Fifteen human studies (total participants 4624) were included according to stablished criteria. The coagulation abnormalities (hemorrhagic symptoms, abnormal fibrinogen and activated partial thromboplastin time) were associated with acute kidney injury in
\end{abstract}

* Correspondence: pollylemos78@gmail.com https://doi.org/10.1590/1678-9199-JVATITD-2019-0076

Received: 15 January 2020; Accepted: 10 June 2020; Published online: 10 July 2020 
the most recent studies reported. The findings observed in this review provide up-todate evidence about the acute kidney injury pathogenesis following Bothrops syndrome. Studies pointed out that coagulation abnormalities comprise the major pathway for acute kidney injury development. This review may improve patient management by primary healthcare providers, allowing earlier diagnosis and treatment of Bothrops venom-related acute kidney injury.

\section{Background}

Snakebite envenoming was considered again a neglected tropical disease by World Health Organization (WHO) in 2017 [1]. Renal damage is a complication in this scenario and can be associated with higher risk of death.

Acute kidney injury (AKI) defined as an increase in serum creatinine $\geq 0.3 \mathrm{mg} / \mathrm{dL}(26.5 \mu \mathrm{mol} / \mathrm{L})$ within 48 hours or increase in $\geq 1.5$ times baseline or urine volume $<0.5 \mathrm{~mL} / \mathrm{kg} / \mathrm{h}$ for 6 hours [2]. The incidence of AKI in developing countries varies between $0.7 \%$ to $31.0 \%$ and there is great heterogeneity in different areas [3]. In this context, AKI is reported in young persons caused by a single clinical condition, such as infectious diseases and envenoming $[3,4]$.

In Latin America, most snakebites are caused by Bothrops snakes and lead to hemotoxic envenoming. Snakebite-related acute kidney injury (AKI) is a common severe complication of this envenoming that may cause death [5-7]. Severe kidney injury may also require renal replacement treatment (RRT) ranging from 0.7 to $75.0 \%$ of cases to maintain the homeostasis [5, 6, 8-11]. Moreover, hemotoxic snake venoms can provoke kidney abnormalities that contribute to chronic kidney diseases in developing countries $[12,13]$.

Hence, this review focuses on the pathogenesis of Bothrops venom-related AKI, highlighting current studies under a perspective of clinical application. According to the literature, the main pathogenic mechanism of Bothrops venom-induced AKI is attributed to coagulation abnormalities [14]. However, direct action of venom on kidney and its hemodynamic effects, myoglobinuria, hemoglobinuria and immunologic mechanisms may play a minor role as reported in experimental studies [15-21].

\section{Methods}

This review was developed based on the Preferred Reporting Items for Systematic Reviews and Meta-Analyses (PRISMA). Observational, cross-sectional, case-control and cohort epidemiological studies available online were selected, mandatorily those conducted in individuals $\geq 18$ years old and victims of Bothrops bites.

The search was performed in the following databases: Medline/ Pubmed, SciELO and Lilacs, including articles published until December 2019. Some alternative sources, such as reference lists from other studies and reviews on the same topic, were consulted to ensure the inclusion of relevant articles. The search was limited to English, Spanish and Portuguese.
The following descriptors were used according to Medical Subject Headings (MeSH): on Medline/Pubmed and Google Scholar "acute kidney injury" or "kidney disease" and "Bothrops"; on Lilacs and SciELO "kidney disease" or "acute kidney injury" and "Bothrops".

The selection of the papers was performed in a standardized manner by two authors independently. Possible discrepancies were analyzed by a third author. When the title and abstract were not elucidative, a full article analysis was performed.

We identified 261 articles, of which 115 were excluded from the study after reading the title and abstract. A total of 111 articles were selected for full text evaluation, and 95 studies were excluded. The final inclusion therefore comprised 15 studies that met the proposed inclusion criteria and were used for the construction of this review (Figure 1). Newcastle-Ottawa quality assessment scale (NOS) was used to appraise the quality of the cross-sectional and cohort studies included. The selection of more severe patients who looked for health care units and tertiary centers is a risk of bias. Few human studies were included according to inclusion criteria, then, some epidemiological and experimental studies were reported in this scoping review.

\section{Bothrops snakes: variability and distribution}

The variability of snakes in Bothrops genera is remarkable [22]. There are more than 30 endemic species distributed from southern Mexico to Brazil [23]. The incidence and severity of snakebites depend on environmental and human factors [24, 25].

Snakebites are an occupational hazard in rural tropical areas [26-29]. These accidents are more frequent during rainy seasons, the most affected group is young men and lower limbs are the most frequently injured body parts [3]. The distribution of the main Bothrops species in Latin America, based on WHO, can help in the identification of snakes and in the diagnosis of envenoming [23] (Figures 2, 3, 4 and 5).

\section{Bothrops venom}

The notorious variability in Bothrops genera contributes to the wide range of venoms and their biological effects. Several studies have compared the different characteristics among Bothrops venoms [15, 30-39]. There are several biochemical families of toxins in the venom of Bothrops species including snake venom metalloproteinases (SVMs), snake venom serine proteinases (SVSPs), L-amino acid oxidases (L-AAOs) and phospholipases $\mathrm{A}_{2}$ $\left(\mathrm{PLA}_{2} \mathrm{~s}\right)$ [38] (Figure 6). 


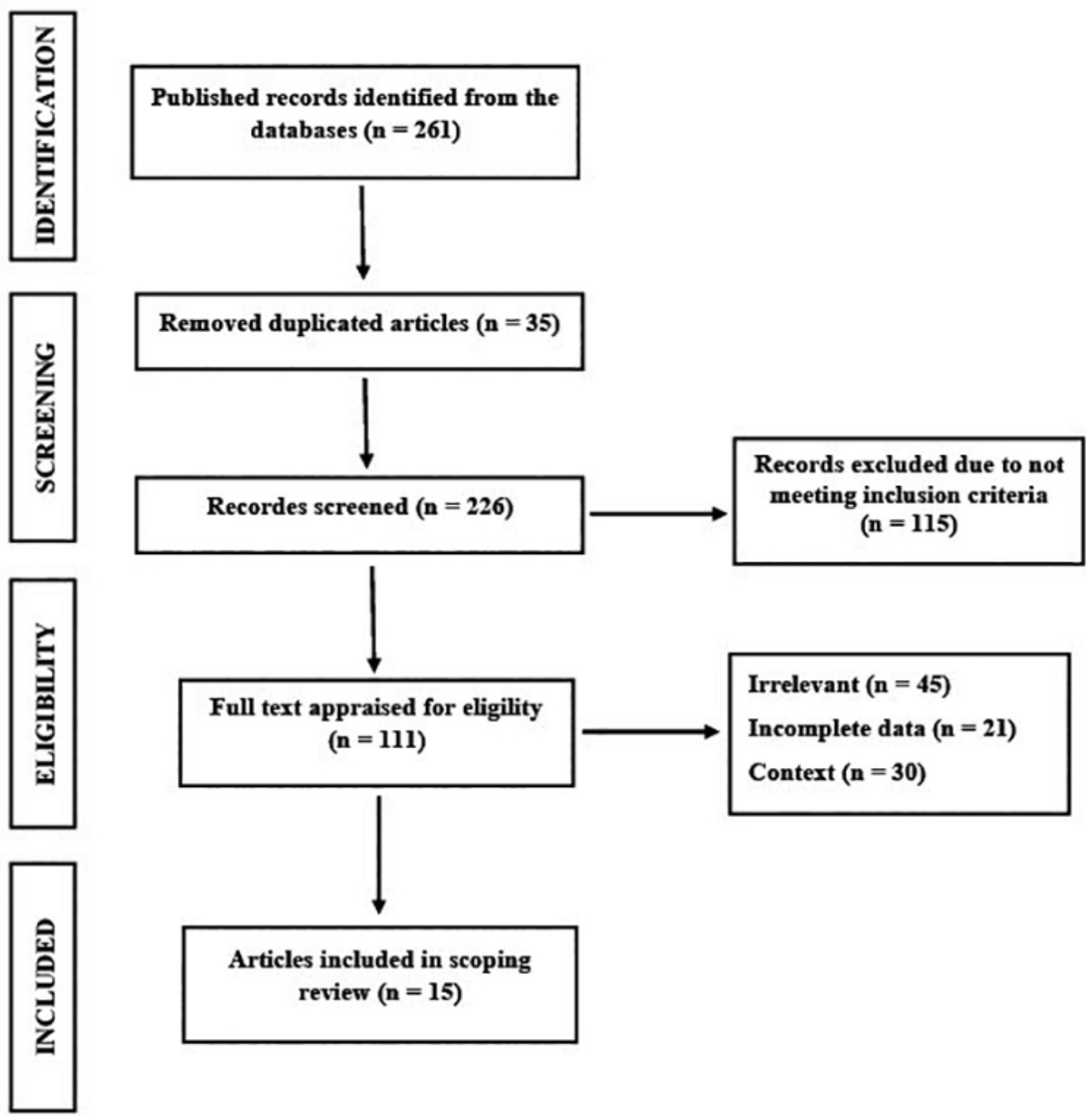

Figure 1. PRISMA flowchart showing the study design process.

SVMs degrade all types of extracellular matrix proteins, disrupt cellular matrix and adhesion, activate chemokines and cytokines, and cleave cell surface receptors. Moreover, they induce apoptosis of vascular adhesion cells. Class P-III SVMs besides inducing hemorrhage, they activate coagulation factors, inhibit platelet aggregation, and provoke local symptoms. For example, jararhagin acts on renal toxicity $[18,38,40-44]$. PLA 2 s have a pivotal role in inflammation by activating arachidonic acid that leads to generation of eicosanoids (prostaglandins and leukotrienes). They also stimulate the hypothalamicpituitary-adrenal axis to produce adrenocorticotropic hormone, corticosteroids, vasopressin and acute phase proteins; as well as cause local manifestations at the bite site and hemodynamic changes [43, 45-48]. SVSPs are highly expressed in kidneys. They possess thrombin-like action with fibrinolytic activity leading to blood coagulation disturbances, vasodilatation and hypotension through nitric oxide-dependent guanylyl cyclase, convert kininogen to kinin, following vascular smooth muscle relaxation, enhance tubular reabsorption of $\mathrm{Na}$ in the collecting duct $[43,49,50]$. L-AAOs cause endothelial injury, platelet aggregation, cellular apoptosis to DNA damage and nephrotoxicity as well as cytotoxicity in Madin-Darby canine kidney (MDCK) cells. 


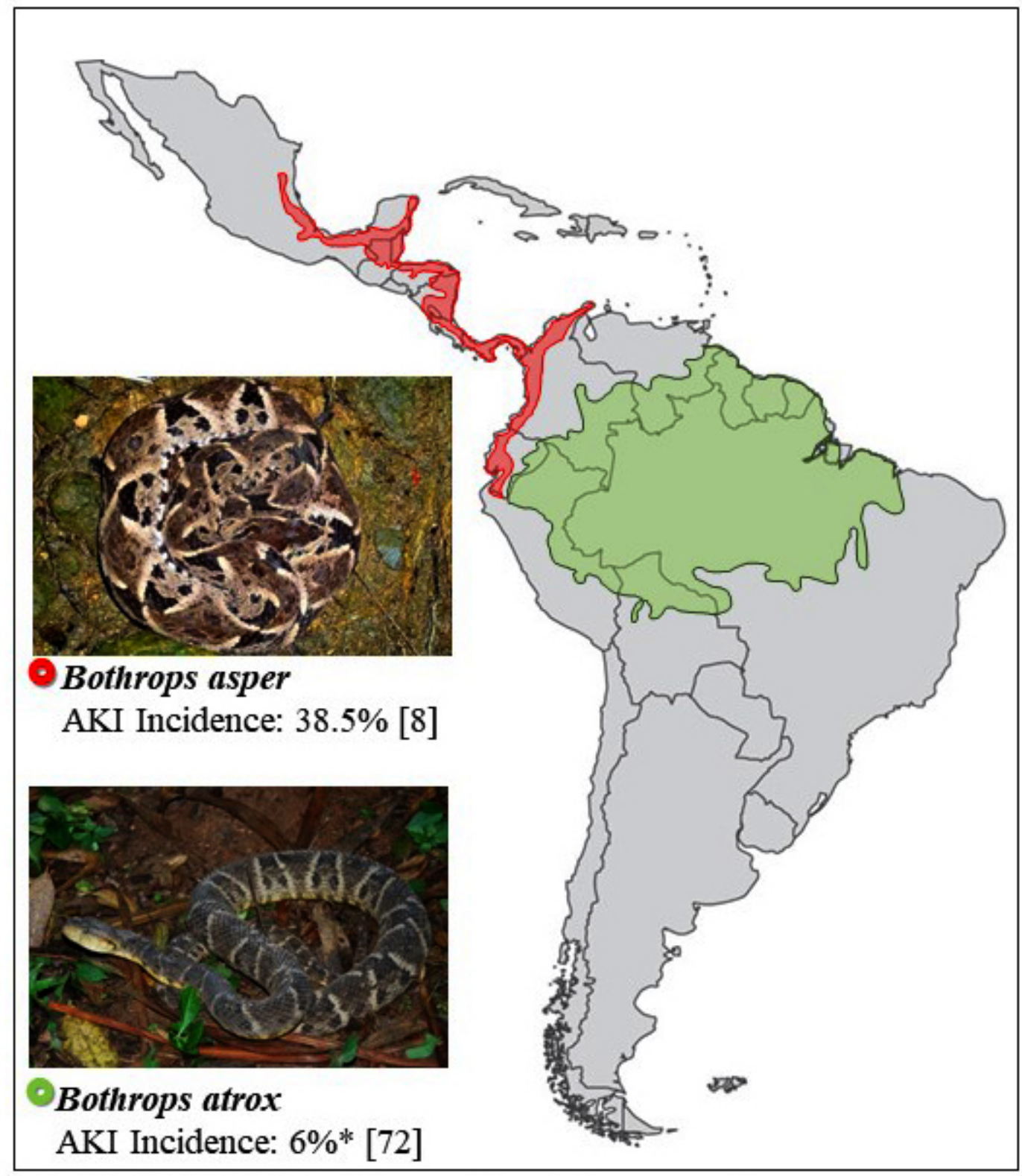

(*) Study included B. atrox, B. lanceolatus and B. venewuelensis

Figure 2. Geographical distribution of Bothrops asper (photo courtesy of Livia Correa, Special Laboratory of Zoological Collections, Butantan Institute, Brazil) and Bothrops atrox (photo courtesy of Marcelo Duarte, Laboratory of Zoological Collections, Butantan Institute, Brazil) and respective incidence of AKI in Latin America.

Snake venom contains multiple proteolytic toxins that may cause systemic as well as renal hemodynamic changes. These toxins also have thrombin-like action and fibrinolytic activity [43]. The SVMs are the most important toxins that are able to degrade all types of extracellular matrix proteins, disrupt cellular matrix and cellular adhesion, cleave cell surface receptors [43], activate chemokines and cytokines [41], as well as induce apoptosis of vascular adhesion cells $[18,40]$. This toxin can activate coagulation factors, inhibit platelet aggregation and induce local symptoms at the site of the bite $[42,44]$.

The correlation between venoms from different species and their key toxic compounds are the mainstay of the specific treatment of Bothrops snakebites [30, 51, 52]. The similarities help the creation of next-generation antivenom therapies, which might improve the management of the patients [53]. 


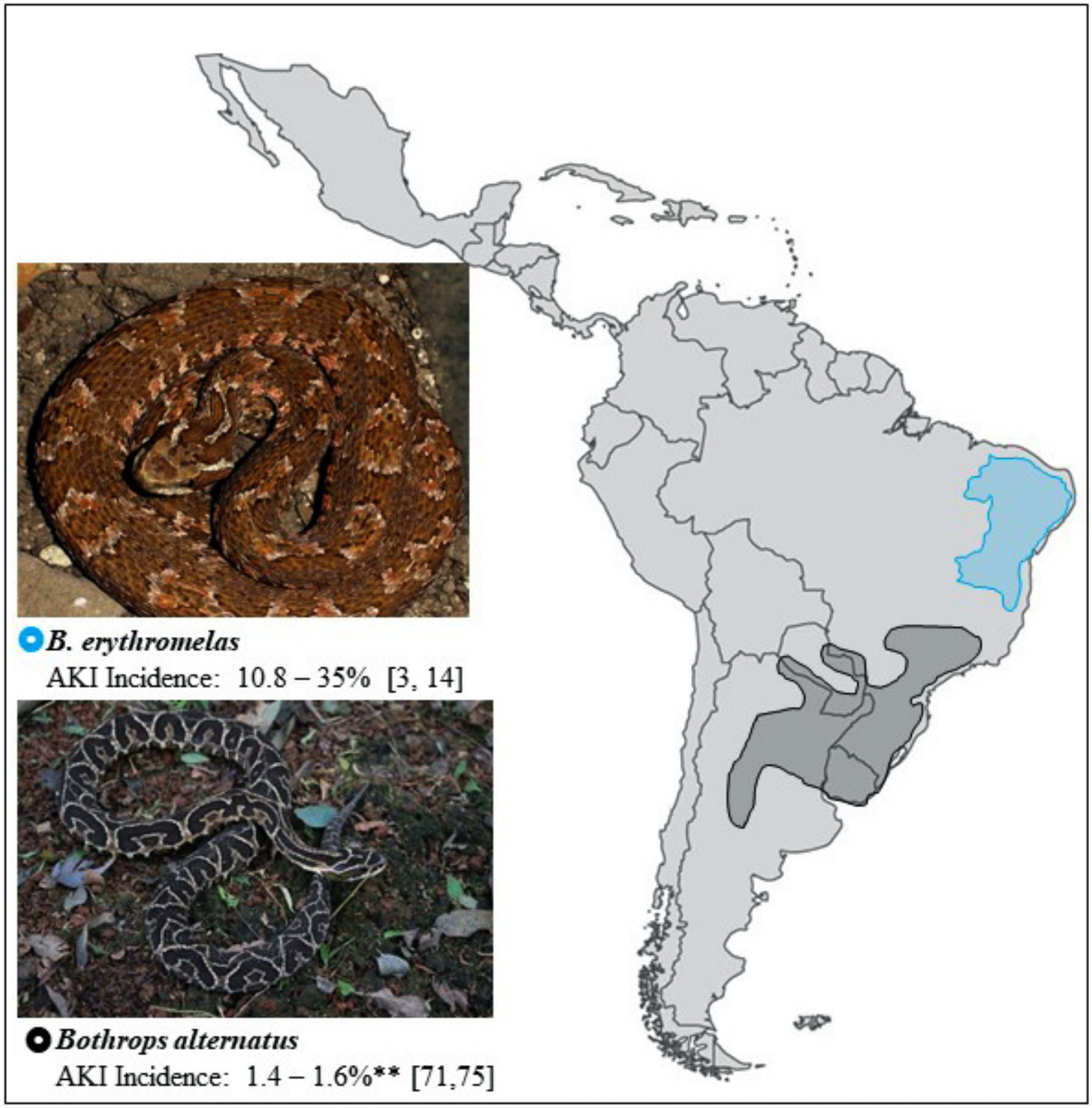

${ }^{(* *}$ ) Studies included B. jararacussu, Bothrops jararaca, B.moojeni, B. alternatus and B. neuwiedi

Figure 3. Geographical distribution of Bothrops erythromelas (photo courtesy of Bruno Cardi, Laboratory of Toxicology and Molecular Neuropharmacology, State University of Ceará, Brazil) and Bothrops alternatus (photo courtesy of Marcelo Duarte) and respective incidence of AKI.

\section{Bothrops envenoming: incidence and implications}

\section{Clinical manifestations}

The expression "Bothrops syndrome" describes the variety of manifestations caused by Bothrops envenoming [54]. However, the ontogenetic variations in venom composition might have clinical implications [55]. The most important feature of Bothrops envenoming is the local effect of proteolytic toxins due to snakebite. After the bite, discrete bleeding is common at the venom inoculation site. Edema, pain, redness and bruising can also be observed [56]. Local inflammation could lead to amputation, especially in patients bitten in the fingers and among those who developed blisters and abscesses at the bite site. Systemic bleeding and renal failure are also possible outcomes [57]. 


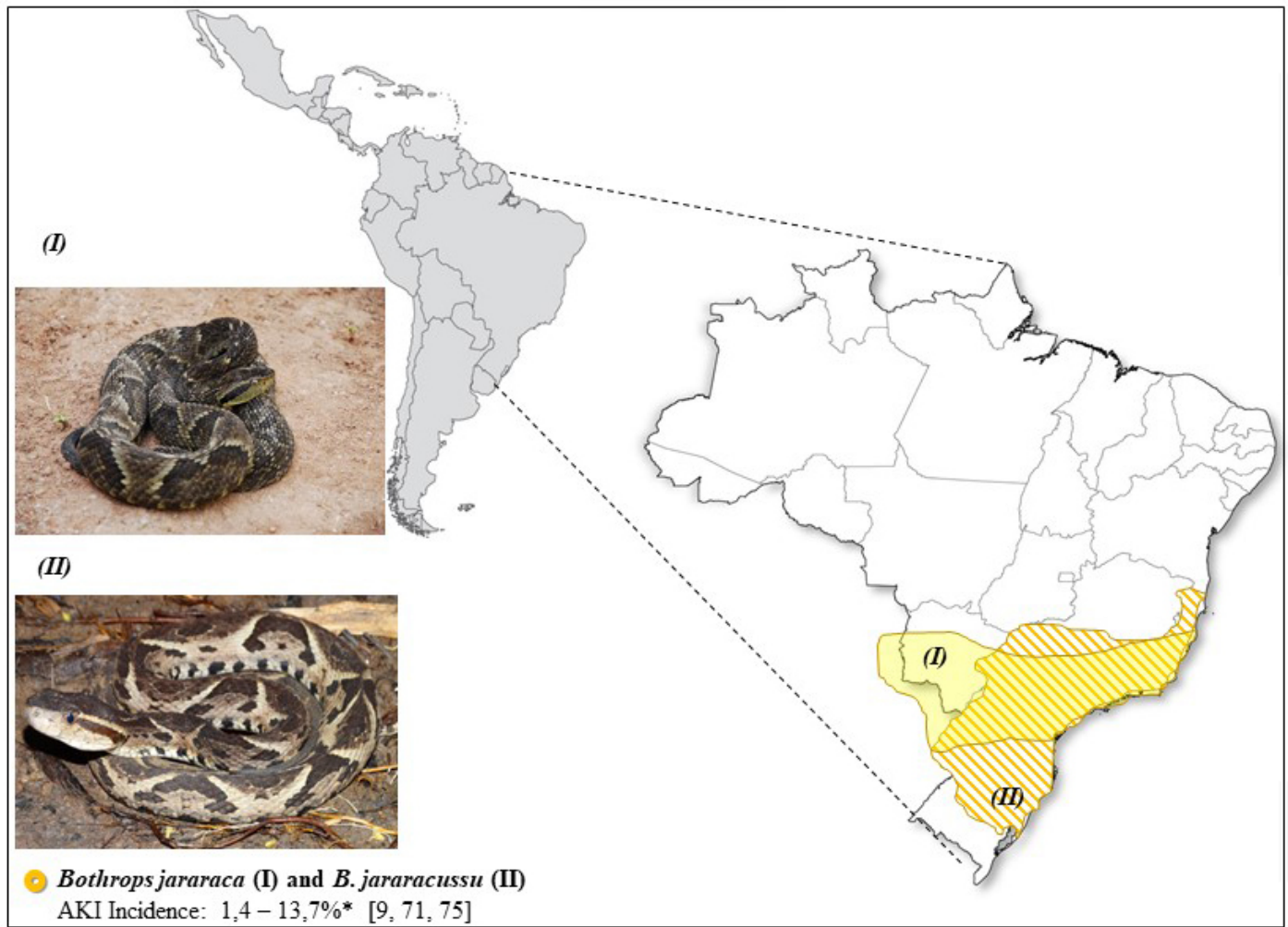

AKI Incidence: $1,4-13,7 \% *[9,71,75]$

*Studies included B. alternatus, B. neuwiedi and B. pradoi

Figure 4. Geographical distribution of Bothrops jararaca (photo courtesy of Marcelo Duarte) and Bothrops jararacussu (photo courtesy of Paulo Bernarde, Federal University of Acre) and the incidence of AKI.

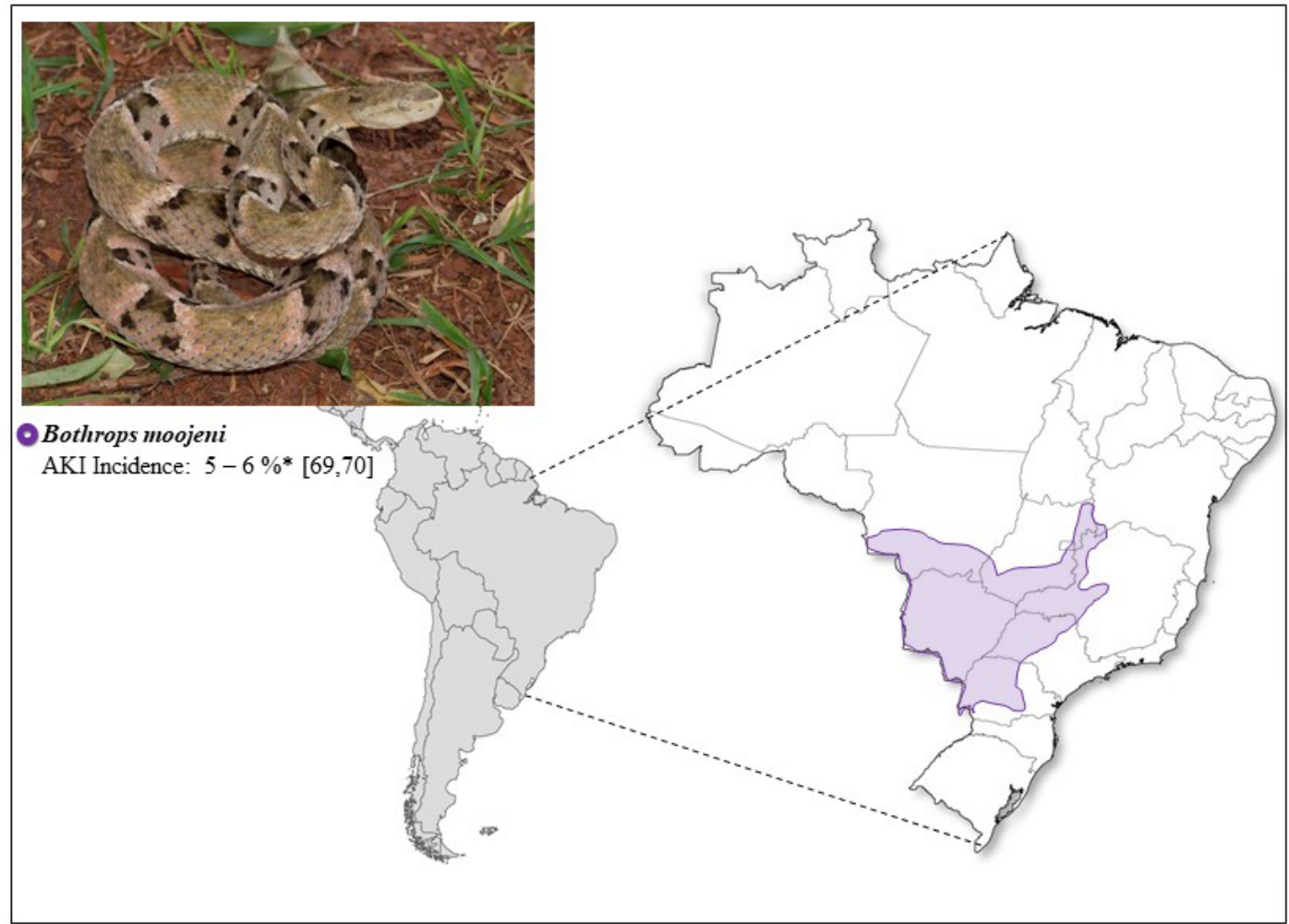

* Study included B. moojeni and B. nerwiedi

Figure 5. Geographical distribution of Bothrops moojeni (photo courtesy of Paulo Bernarde) and the incidence of AKI. 


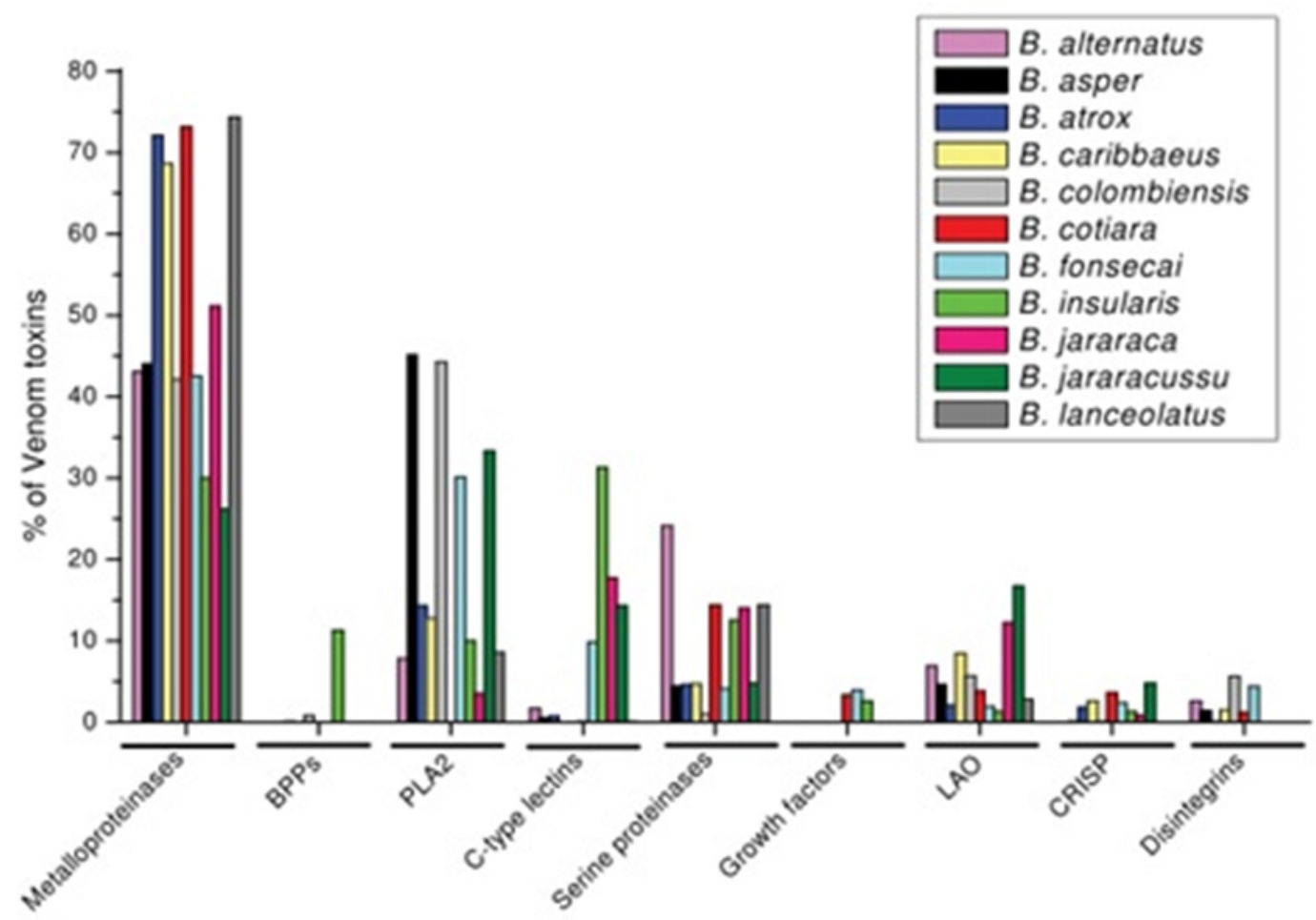

Figure 6. Relative abundance of the major toxin classes in bothropic venoms determined by proteomic analysis. Abundance expressed as a percentage of the total number of toxins identified in each analysis. BPPs: bradykinin-potentiating peptides; PLA; phospholipase A; LAO: L-amino acid oxidase; CRISP: snake venom cysteine-rich secretory proteins [39]. (Reprinted with permission from: Cardoso KC, et al. A transcriptomic analysis of gene expression in the venom gland of the snake Bothrops alternatus (urutu). BMC Genomics. 2010;11:605.)

Bothrops venom contains various biologically active peptides that may elicit an inflammatory response and contribute to cell and tissue damage as well as hemostatic abnormalities. It could activate coagulation factor $\mathrm{X}$, prothrombin and lyses fibrinogen, which leads to hypofibrinogenemia and the production of fragile fibrin [6]. As a consequence, consumption coagulopathy and blood incoagulability may appear, which may lead to death [58]. Systemic effects include spontaneous hemorrhage, disseminated intravascular coagulation and cardiovascular shock secondary to hypovolemia and vasodilation [59]. Cerebral hemorrhage, following multiple manifestations of coagulopathy and AKI, is a severe manifestation and was described in the literature [60].

Coagulation disturbances, bleeding and the presence of lifethreatening complications (cardiovascular shock, AKI and vital organ damage) define the systemic envenomation [61]. Besides, the severity of clinical symptoms has a strong association with the quantity of circulating venom [62]. The extension of edema on hospital admission and the presence of necrosis define the local envenoming grade and guides the number of antivenom vials that must be used in specific treatment [63].

\section{Mortality due to Bothrops envenoming}

Death following snakebites are infrequent [64]. The fatality rate due to Bothrops envenomation also varies among countries and regions within a country [61]. The average annual incidence in American countries is about 57,500 snake bites (6.2 per 100,000 people) and mortality is close to 370 deaths ( 0.04 per 100,000 people), that is, between one third and half of the previous estimates [24]. In Brazil there were 202,288 cases of Bothrops accidents between 2004 and 2016, and only 752 deaths, resulting in a lethality rate of $0.37 \%$ [65]. Comparative toxicological and biochemical studies performed on the venoms of adult $B$. asper specimens from Panama revealed high similar profile of activities with quantitative differences among venoms from different countries (Guatemala, Honduras, Costa Rica, Colombia, and regions of Mexico). Interestingly, the manufactured polyvalent antivenom neutralized the lethality of the venoms of the four regions and showed a pattern of strong cross-reactivity against the various proteins of these venoms [51]. In Brazil, Costa Rica and Panama, antivenoms are freely available for patients in all reference hospitals and health centers [61], which is an effective measure to decrease mortality. Moreover, studies have suggested a delayed time between snakebite and antivenom administration in patients with higher incidence of AKI, therefore it is important to observe the antivenom distribution chain $[5,66]$.

\section{Bothrops venom-related AKI: burden in developing countries}

\section{Incidence of AKI following Bothrops envenoming}

There are several epidemiological studies that describe AKI. However, only a few applied the AKI definition according to 
KDIGO, AKIN or RIFLE criteria [5, 8, 11, 14, 56, 67-74]. Data from retrospective series described a great variable in AKI incidence, 1.4 to $44.4 \%[5,8,11,56,66-74]$. Therefore, the real incidence of AKI due to Bothrops envenoming is underestimated, not only because of the ambiguity of the definition, but also the absence of notification in some rural areas [63] (Table 1).

\section{Characteristics of Bothrops venom related AKI}

The acute kidney injury in Bothrops accidents are commonly oliguric, severe and occurs within the first hours after the snakebite [6, 10, 59, 61, 63, 75-78]. Da Silva et al. [79] described 29 patients with AKI due to bothropic and Crotalic accidents in an intensive care unit. Crotalic accidents commonly provoke oliguria or anuria later than Bothrops accidents. Therefore, it is important to consider the oliguria when the hydration is stablished.

\section{Pathophysiology}

\section{The role of experimental studies for scientific evidence}

The direct effects of Bothrops venom in isolated renal perfusion experimental models have provided major insights about the pathogenesis of AKI [15, 18, 19, 21, 48, 80, 81] (Table 2). AKI could vary according to differences in venom potency and composition [31, 32]. The renal cells exposed to Bothrops venom mimic the changes in the human body. The concentration of venom in the perfusion fluid was estimated according to the amount inoculated by Bothrops snakes in a person weighting $60 \mathrm{~kg}$. Decreased renal vascular resistance is observed and can occur due to blockade of either $\left[\mathrm{Na}^{+}\right]$and $\left[\mathrm{Ca}^{2+}\right]$ channels or opening of $\left[\mathrm{K}^{+}\right]$channels [43].

The pharmacokinetic profile in rat exposure of Bothrops venom revealed important aspects of the distribution and route of elimination $[82,83]$. Bothropic venom may be found in renal tissue associated with morphological damage and renal dysfunction [82]. The presence of Bothrops alternatus venom in renal tissue was detected $30 \mathrm{~min}$ post-venom exposition, but it decreased progressively thereafter, in parallel with serum venom concentrations [82]. Immunohistochemistry detected it in glomeruli, proximal, distal tubules, vascular and perivascular tissue. The venom appeared in urine 3, 6- and 24-hours postinjection. Oliguria occurred from 3 hours to 7 days after venom administration [84-86], whereas proteinuria was more observed in the first 3 hours. Creatinine clearance decreased progressively until 24 to 48 hours after administration of venom, then returned to normal. Circulating venom showed biexponential kinetics, with no venom after 7 days post-exposition. Glucose, ketone, leucocyte and occult blood abnormalities occurred mainly during the first 6 hours after venom injection [82].

Moreover, systemic hemodynamic changes, such as a decrease in blood pressure occurred in many animal models after perfusion with bothropic venom $[48,80]$. Vascular permeability may contribute to hypovolemia, but further studies are required [43]. Most animal toxins close calcium and sodium channels leading to hypotension. These ion channels contribute to hemodynamic effects of Bothrops enzymes and peptides [87].

The identification of new Bothrops toxins, such as vascular endothelial growth factor (VEGF), contribute to the understanding of kidney injury pathogenesis [88, 89]. A bioactive proline-rich decapeptide, part of C-type natriuretic peptide precursor from Bothrops jararaca, Bj-BPP-10c, displayed a strong and sustained anti-hypertensive action. The activation of arginosuccinate synthetase was the major protein linked to the peptide and led to an increase of nitric oxide [89]. The Bj-BPP-10c could be considered as a lead molecule to develop therapeutic agents for the treatment of various diseases based on NO deficiency as cause or effect. [89].

\section{Main pathways}

The pathways associated with AKI development in bothropic envenoming are based on scientific evidence distributed according to the main clinical manifestations in the literature.

The most important pathway in Bothrops venom-related acute kidney injury is probably coagulopathy. However, almost all included studies were cross-sectional and just three presented clear definition of acute kidney injury according to stages of KDIGO, AKIN or RIFLE [5, 14, 66]. These studies reported the abnormal activated partial thromboplastin time (aPTT), bleeding symptoms and abnormal LDH level which are factors associated with AKI development $[5,14,66]$. The increase of LDH levels was observed in recent case reports about thrombotic microangiopathy in Bothrops envenoming and expressed the high cellular turnover and necrosis following the increase of creatinine levels [90, 91].

In general, the mechanisms of Bothrops venom-induced AKI have been attributed to [63, 92] (Figure 7):

- the direct action of venom on kidney and its hemodynamic effects;

- myoglobinuria;

- hemoglobinuria;

- glomerular microthrombi deposit due to coagulation abnormalities;

- immunologic mechanisms in a minor proportion.

\section{Direct nephrotoxicity}

The evidence of direct nephrotoxicity due to Bothrops venom comes from studies in animal models and cell cultures $[15,18$, 19, 21, 48, 80, 81, 84-86, 93]. Although there were no human studies on it, the importance of the animal models offered an overview about this pathway. The hemodynamic changes in kidneys reported above (Table 2) varied according to the snake species, but most cases presented a decrease in renal vascular resistance (RVR), glomerular filtration rate (GFR) and urine flow (V), an increase of excretion of $\mathrm{Na}$ and $\mathrm{K}$. Some venoms (Bothrops jararacussu, B. erythromelas and B. moojeni), however, presented an increase of GFR and V $[85,86,93]$. 
Table 1. Incidence of nephrotoxic AKI after bothropic envenoming.

\begin{tabular}{|c|c|c|c|c|c|c|c|}
\hline Definition of AKI & Species* & $\mathbf{n}$ & $\begin{array}{l}\text { AKI } \\
\text { n (\%) }\end{array}$ & $\begin{array}{c}\text { Dialysis } \\
\text { n (\%) }\end{array}$ & $\begin{array}{c}\text { Coagulopathy } \\
\text { n (\%) }\end{array}$ & $\begin{array}{c}\text { Mortality } \\
\text { n (\%) }\end{array}$ & Reference \\
\hline **⿻丷木 & Bothrops sp. & 67 & $7(10.5 \%)$ & - & - & - & [68] \\
\hline - & Bothrops moojeni & 37 & 0 & - & $27(72.7 \%)$ & $1(2.9 \%)$ & [56] \\
\hline- & $\begin{array}{l}\text { Bothrops jararaca, } \\
\text { Bothrops jararacussu }\end{array}$ & 27 & - & $9(33.3 \%)$ & - & - & {$[11]$} \\
\hline- & Bothrops sp. & 114 & $7(6 \%)$ & - & $16(14 \%)$ & 0 & {$[67]$} \\
\hline **⿻丷木 & Bothrops moojeni & 57 & $3(6 \%)$ & - & - & - & [69] \\
\hline **⿻丷木 & $\begin{array}{c}\text { Bothrops moojeni, } \\
\text { and Bothrops neuwiedi }\end{array}$ & 292 & $15(5 \%)$ & - & $158(54 \%)$ & $3(1 \%)$ & {$[70]$} \\
\hline- & Bothrops jararacussu & 29 & $4(13.7 \%)$ & $2(7.0 \%)$ & $14(48.2 \%)$ & $3(10 \%)$ & [9] \\
\hline 米米 & $\begin{array}{c}\text { Bothrops jararaca (97.5\%), } \\
\text { Bothrops jararacussu, } \\
\text { Bothrops neuwiedi, } \\
\text { Bothrops moojeni, } \\
\text { Bothrops alternatus } \\
\text { and Bothrops pradoi }\end{array}$ & 3,139 & $50(1.6 \%)$ & $22(0.7 \%)$ & $1729(55.1 \%)$ & $9(0.29 \%)$ & {$[75]$} \\
\hline- & $\begin{array}{l}\text { Bothrops lanceolatus, } \\
\text { Bothrops venezuelensis } \\
\text { and Bothrops atrox }\end{array}$ & 60 & $1(6.0 \%)$ & - & $33(55 \%)$ & 0 & {$[72]$} \\
\hline **⿻丷木 & $\begin{array}{c}\text { Bothrops jararaca, } \\
\text { Bothrops alternatus } \\
\text { and Bothrops neuwiedi }\end{array}$ & $73 * * * *$ & $1(1.4 \%)$ & - & $34(60.7 \%)$ & 0 & {$[71]$} \\
\hline- & Bothrops asper & 39 & $15(38.5 \%)$ & $13(33.3 \%)$ & $31(79.5 \%)$ & 40 (10.3\%) & {$[8]$} \\
\hline- & Bothrops sp. & 165 & 0 & - & - & $1(0.5 \%)$ & {$[124]$} \\
\hline RIFLE and AKIN & Bothrops erythromelas & 276 & $30(10.8 \%)$ & $15(5.43 \%)$ & $97(35.1 \%)$ & $4(1.5 \%)$ & {$[5]$} \\
\hline AKIN & Bothrops sp. & 186 & $24(12.9 \%)$ & $31(16.7 \%)$ & $180(97.3 \%)$ & 0 & [66] \\
\hline KDIGO & Bothrops erythromelas & 63 & 22 (35\%) & - & $44(70 \%)$ & 0 & {$[14]$} \\
\hline
\end{tabular}

*Identification of the species of Bothrops carried out in a few cases. **Elevated levels of serum creatinine which later returned to normal range. ***Under 15 years old. (-) Not described.

Renal pathologic changes in patients with AKI caused by snakebites include tubular necrosis, cortical necrosis, glomerulonephritis and vasculitis. Moreover, the tubular epithelial cells are the main targets of these venoms [43]. Glomerular changes seem to be responsible for the proteinuria and could contribute to nephrotoxicity, demonstrated for the first time in an animal model after intravenous administration of $B$. moojeni venom in rats. Mesangiolysis, microaneurysm formation and pedicel damage were consequences of the high proteolytic and PLA ${ }_{2}$ activities of this venom [94]. The leakage of electrolytes $\left[\mathrm{Na}^{+}\right],\left[\mathrm{K}^{+}\right]$in experimental models represent this tubular injury. Castro et al. [95] reported for the first time the direct toxicity of $B$. jararaca venom on isolated rat renal proximal tubules. The study demonstrated the direct effect of venom on proximal tubules independently of extracellular calcium and partially mediated by lipid peroxidation. The administration of antivenom therapy, simultaneous or up to $15 \mathrm{~min}$, prevented or delayed the tubular toxicity.

Several studies have confirmed the involvement of Bothrops venom components in apoptosis [15, 17-19, 21, 40,42, 46]. De Morais et al. [21] analyzed the cellular death induced by $B$. leucurus venom through flow cytometry with annexin $\mathrm{V}$ and propidium iodide. They concluded that death occurred predominantly by necrosis but may involve apoptosis in lower concentrations of the venom. In 2014, Collares-Buzato and Cruz-Hofling [96] reported that in renal corpuscle, the decrease in glomerular content of ZO-1, the disorganization of laminin within the glomerular basal membrane and the increase in vinculin podocytes expression led to the impairment of the glomerular filtration barrier. The cell-cell and cell-matrix 


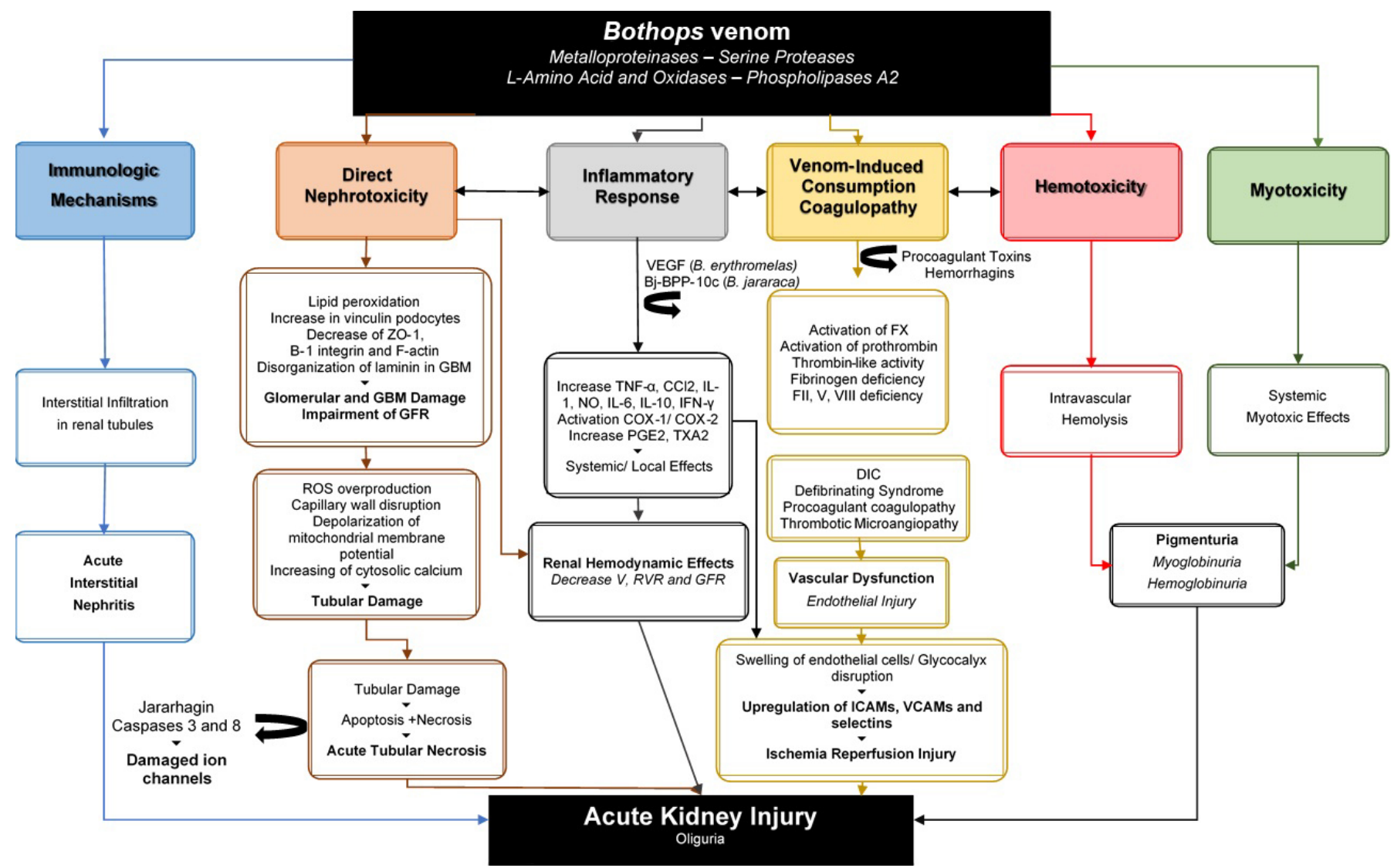

Figure 7. Schematic representation of pathophysiology of bothropic venom-related AKI. The main mechanisms are based on updated scientific evidences reported in the literature. AIN: acute interstitial nephritis; ATN: acute tubular necrosis; Bj-BPP-10c: bioactive proline-rich decapeptide, part of C-type, natriuretic peptide precursor from B. jararaca; DIC: disseminated intravascular coagulation; RVR: renal vascular resistance; GFR: glomerular filtration rate; V: urinary flow; FENa: fractional excretion of sodium; FEK: fractional excretion of potassium; F X, F VIII, F V, F II: coagulation factors X, VIII, V, II; ROS: reactive oxygen species; VEGF: vascular endothelial growth factor from B. erythromelas; GBM: glomerular basement membrane; ZO-1: tight junctional protein; GFB: glomerular filtration barrier; VICC: venom- induced consumption coagulopathy.

Table 2. Renal hemodynamic changes in experimental studies with Bothrops venom

\begin{tabular}{|c|c|c|c|c|c|c|c|}
\hline Species & $\begin{array}{c}\text { Toxin } \\
\text { (crude/compound) } \\
\end{array}$ & RVR & GFR & $\mathbf{v}$ & FENa & FEK & References \\
\hline \multirow{5}{*}{ Bothrops jararaca } & Crude & $* \nabla$ & $\nabla$ & $\checkmark$ & $\checkmark$ & 米*⿻丷木 & [80] \\
\hline & Crude & **⿻丷木 & $\checkmark$ & $\checkmark$ & $\Delta$ & **** & [81] \\
\hline & Crude & $\checkmark$ & $\checkmark$ & $\checkmark$ & $\Delta$ & ***** & [84] \\
\hline & Crude (southern Brazil) & - & $\checkmark$ & $\checkmark$ & $\Delta$ & $\Delta$ & \multirow[b]{2}{*}{ [15] } \\
\hline & $\begin{array}{c}\text { Crude } \\
\text { (southeastern Brazil) }\end{array}$ & $\checkmark$ & $\Delta$ & $\Delta$ & $\boldsymbol{\Delta}$ & $\boldsymbol{\Delta}$ & \\
\hline \multirow{2}{*}{ Bothrops moojeni } & Crude & $\checkmark$ & $\Delta$ & $\Delta$ & $\Delta$ & $\Delta$ & \multirow{2}{*}{ [85] } \\
\hline & Myotoxin I & $\Delta$ & $\Delta$ & $\Delta$ & $\Delta$ & $\Delta$ & \\
\hline \multirow[t]{2}{*}{ Bothrops erythromelas***** } & Crude & $\checkmark$ & $\nabla / \Delta$ & $\Delta$ & $\Delta$ & $\Delta$ & [86] \\
\hline & Crude & $\nabla$ & $\nabla$ & $\checkmark$ & $\checkmark$ & - & \multirow{2}{*}[48]{} \\
\hline \multirow[t]{2}{*}{ Bothrops marajoensis } & $\mathrm{PLA}_{2}$ & - & - & - & $\Delta$ & $\Delta$ & \\
\hline & L-amino acid oxidase & $\checkmark$ & $\checkmark$ & $\checkmark$ & $\Delta$ & - & [19] \\
\hline Bothrops leucurus******* & Crude & $\checkmark$ & - & - & $\Delta$ & - & [21] \\
\hline Bothropoides pauloensis & Crude & $\nabla$ & $\mathbf{v}$ & $\nabla$ & $\boldsymbol{\nabla}$ & $\Delta$ & [18] \\
\hline
\end{tabular}

RVR: renal vascular resistance; GFR: glomerular filtration rate; V: urinary flow; FENa: fractional excretion of sodium; FEK: fractional excretion of potassium; FECl: fractional excretion of chloride. $* \nabla$ Decrease. $* *-$ Increase. $* * *$ Not determined. $* * * * G F R$ decreased at 60 min and increased at 120 min. $* * * * * T h e$ effect on urinary flow and GFR was transient and returned to normal at $120 \mathrm{~min}$ of venom perfusion. (-) No change. 
adhesion proteins seem to be molecular targets in the B. moojeni venom-induced kidney injury [96]. Dantas et al. [19] published the renal alterations caused by Bothrops venom in MDCK cells. L-AAOs were cytotoxic to MDCK cells and induced late apoptosis, so these proteins acted like nephrotoxic compounds.

Similarly, Marinho et al. [18] evaluated the effect of $B$. pauloensis venom in isolated perfused kidney and MDCK cells. They detailed the venom cytotoxicity on renal epithelial cells and apoptosis, through the caspases 3 and 7 activation, mitochondrial membrane potential collapse and reactive oxygen species (ROS) overproduction. Likewise, De Sousa et al. [17] described the apoptosis induced by $B$. erythromelas venom on MDCK cells with the involvement of the caspases 8 and 3, which probably occurs through the extrinsic pathway. The apoptosis required only low doses of venom, while necrosis required high doses and the cellular death occurred until $24 \mathrm{~h}$ after the exposition.

The participation of ion channels (potassium, chloride and calcium) in apoptosis requires attention [87]. The expression and activity of $\left[\mathrm{Na}^{+} / \mathrm{K}^{+}\right]$-ATPase associated to histological and functional alterations due to $B$. alternatus venom in rats were reported and seemed to attenuate the renal dysfunction in the early hours after envenomation [97]. The findings of proteinuria, decreased GFR, increased $\mathrm{FE}\left[\mathrm{Na}^{+}\right]$, increased $\mathrm{FE}\left[\mathrm{K}^{+}\right]$and significantly increased gene expression of the $\alpha 1$ subunit of $\left[\mathrm{Na}^{+} / \mathrm{K}^{+}\right]$-ATPase 6 and 24 hours after venom injection were reported. Additionally, cytoskeleton alterations, F-actin disruption in Bowman's capsule and in the brush border of renal tubules were described [97].

\section{Myoglobinuria}

Studies reported slight increase of creatine phosphokinase level in Bothrops envenoming $[14,66]$. The local muscle injury caused by Bothrops venom could contribute to AKI. The occurrence of such muscle injury does not provoke systemic myotoxic effect, as it occurs with Crotalus venom [6, 98]. Melo et al. [99] reported the effects of $B$. jararacussu venom on rat and frog muscles, which confirmed the considerably increase in plasma creatine kinase (CK) activity following the injection of venom. Mourada-Silva et al. [100] described differences of myotoxic proteins among venoms from Bothrops species. The myotoxicity induced by the crude venoms from $B$. jararacussu, B. moojeni, $B$. neuwied and $B$. prado $i$ were five to eight-fold higher than those obtained with B. alternatus, B. atrox, B. cotiara, B. erythromelas and $B$. jararaca. Nevertheless, Burdmann et al [81] carried out a study in rats exposed to $B$. jararaca venom and showed that the levels of CK were not differently affected in comparison with lactate dehydrogenase (LDH) levels.

Despite the occurrence of rhabdomyolysis induced by $\mathrm{PLA}_{2}$ resulting in myoglobinuria, it is not significant in Bothrops accidents. Nevertheless, it could contribute to AKI with hemoglobinuria.

\section{Hemoglobinuria and hematuria}

Studies often reported abnormalities in urine [11]. Hematuria can be microscopic or macroscopic and the outcome is usually favorable [101]. Several mechanisms may account for the tubular injury found: mechanical obstruction by red blood cell casts, cytotoxic effects of oxidative stress induced by hemoglobin, heme iron released from red blood cells [101] and the worsening of renal vasoconstriction. Rezende et al. [80] detected hematuria and hemoglobinuria at 24 and 48 hours after intraperitoneal injection of $B$. jararaca venom in rats. Hrovat et al. [102] carried out a prospective study about renal dysfunction in dogs envenomed by cytotoxic $(\mathrm{n}=11)$ and neurotoxic snakebites $(\mathrm{n}=8)$, evidencing $80 \%$ of hematuria 24 hours after envenomation.

\section{Venom-induced consumption coagulopathy (VICC)}

This is the most likely pathway in AKI due to Bothrops snakes: the association between AKI and abnormal coagulation, including abnormal aPTT, hypofibrinogenemia and hemorrhagic symptoms, as soon as the increase of $\mathrm{LDH}$ is reported $[5,14,66]$. Snakebite induces thrombotic microangiopathy, characterized by the triad of AKI, thrombocytopenia, microangiopathic and haemolytic anaemia, which could lead to renal cortical necrosis [103-105]. Hemorrhagins contained in venoms of some snakes such as Bothrops spp. [40, 42, 44, 106] can cause this coagulopathy. Moura-da-Silva and Baldo [44] reported the presence of jararhagin, a metalloproteinase isolated from $B$. jararaca venom. The targets of jararhagin comprise the vascular endothelium, platelets, coagulation factors and other cell systems as inflammatory cells and their mediators [44].

Few studies reported the occurrence of thrombotic microangiopathy (TMA) in patients following Bothrops snakebite with thrombocytopenia, anemia with blood films showing fragmented red cells, haptoglobin consumption, increase in serum lactate dehydrogenase and a progressive increase of serum creatinine [104, 105]. Torrez et al. [107] reported the association between AKI and prolonged thrombocytopenia in a 37-year-old man admitted to a hospital after snakebite due to Bothriopsis bilineata in the Brazilian Amazon, presenting oliguria, darkcolored urine, incoagulability and thrombocytopenia. A study performed in adult patients after Bothrops snakebite revealed a strong predisposition to development of coagulation abnormalities (aPTT) and AKI development [14]. However, snakebite-associated TMA is a poorly understood phenomenon thus further studies are required to improve the management of these patients [108].

Two possible aggravating factors may contribute to the renal cortical necrosis: renal hypo-perfusion and vascular endothelial injury through a direct or indirect mechanism and the release of circulating substances (for example in intravascular hemolysis) [109]. The formation of microthrombi in blood and leukocyte migration through endothelial cells into renal interstitial compartment could contribute to vascular dysfunction. This dysfunction is an early and prominent factor in AKI, leading to ischemia/reperfusion (I/R) injury, with consequent impairment of blood flow and its regulation. In I/R injury, there is swelling of endothelial cells, disruption of the glycocalyx and endothelial monolayer, and upregulation of adhesion molecules [intercellular 
adhesion molecules (ICAMs), vascular cell adhesion molecule-1 (VCAMs), and selectins) resulting in an increased leukocyteendothelium interactions with interstitial edema in the interstitial compartment [110].

\section{Immunologic mechanisms}

Immunologic phenomena seem to contribute to the snake venom related AKI in a minor role. There was no study included about the immunologic evidences associated with AKI development in Bothrops envenoming. Acute interstitial nephritis (AIN) has been observed in viperid envenoming $[92,111,112]$. The mechanism of AIN in snakebite seems to be secondary to the immunogenic effects of snake venom [113]. Severe renal failure with a prolonged clinical course is common [92] with the necessity of hemodialysis in most cases [113]. Interestingly, this clinical course was unusually prolonged when compared with tubular necrosis [112]. Low platelets and oliguric renal failure are prevalent, but urine sediment could not have anything remarkable, like eosinophiluria $[112,113]$.

Few cases are reporting the occurrence of AIN [111-114] and the majority of these were in Russell's viper snake. Sitprija et al. [112] described the occurrence of AKI with prolonged oliguria in patients following Russel's viper bite. The AIN was observed in renal biopsy revealing interstitial nephritis in addition to tubular necrosis and mesangial proliferation. No immunoglobulins and C3 were detectable in this case. Gundappa et al. [111] reported a similar case AKI following a viperid snakebite due to AIN. They described an oliguric AKI with the necessity of hemodialysis. Interestingly, the patient presented a complete recovery of renal function without the establishment of steroids. Golay et al. [114] reported five cases of AIN after Russell's viper envenomation. These cases presented severe AKI with hemodialysis requirement. Renal biopsies showed extensive interstitial inflammation in all cases reported. Priyamvada et al. [113] carried out research aiming to detect clinical and pathological characteristics of patients who developed AIN following snakebite envenomation. Eighty-eight patients were admitted during the study period and seven biopsies were conducted. There were five patients with AIN. All these cases presented low platelets, oliguric renal failure requiring hemodialysis and received corticoids.

\section{Early diagnosis and management}

Investment on the training of health professionals is critical in the initial management of the patient. The use of electronic medias may improve the early diagnosis [4].

The recognition of risk factors of AKI development following Bothrops snakebites leads to earlier measures which reduce the renal damage $[5,6,8,61,63,70,95]$. Some information suggested a positive correlation among AKI and age, body surface area, prolonged time before treatment, bite site, hospitalization time, snake age and amount of inoculated venom. High level of lactate dehydrogenase (LDH) and local bleeding were recently independently associated with AKI development [66]. Disseminated intravascular coagulation, leukocytosis and lower serum albumin were associated with AKI in a retrospective study carried out in a region of Turkey where viper snakes are the commonest snakes [115]. It is important to look for comorbidities associated with AKI genesis, such as systemic arterial hypertension, previous diabetes, cardiac diseases or even previous kidney diseases [66].

Considering the chance of developing AKI following Bothrops envenoming, the immediate care must include adequate hydration and blood pressure monitoring $[63,116]$. This measure could decrease the kidney damage associated with myoglobinuria, hematuria and hemoglobinuria. Moreover, it is crucial to monitor the local lesion, in order to prevent compartmental syndrome, which could lead to lactic acidosis and could worsen renal function.

Additional tests are recommended in Bothrops accidents following AKI, such as laboratorial tests (coagulation tests, complete blood count, urinalysis, electrolytes, arterial or venous gasometer). Nephrologist's opinion should be required early in cases of severe increase of creatinine (such as stages 3, 4 or 5 of KDIGO) [2].

Recently, urinary neutrophil gelatinase-associated lipocalin (NGAL) and monocyte chemoattractant protein 1 (MCP-1) were good biomarkers in predicting AKI in Bothrops envenoming [14]. Fractional excretion of potassium $\left(\mathrm{FE}\left[\mathrm{K}^{+}\right]\right)$emerged as another diagnostic tool to predict early AKI. Positive correlation between urinary NGAL and urinary MCP-1 with proteinuria and fractional excretion of sodium $\left(\mathrm{FE}\left[\mathrm{Na}^{+}\right]\right)$may indicate glomerular and tubular injury. Defects in urinary concentrations highlighted asymptomatic abnormalities, which deserve further study [14].

Studies reported chronic kidney disease, prehypertension and hypertension in snakebite patients during the follow-up period. [12]. New biomarkers could be useful to understand the continuum between AKI and CKD by the primary care physicians [13].

Proteomic and molecular approaches can be important to understand the clinical manifestations and physiopathology of victims of Bothrops snakebite with AKI, as well as to improve their treatment [117]. Treatment of snakebite victims must begin as soon as possible and the correct dose of antivenom is the standard treatment [63]. Developing a cheap antivenom with diminished adverse reactions is required [116]. Moreover, the presence of AKI signalizes severe envenomation and demands high doses of antivenom [118].

Recently, a significant activation of the hepatocyte growth factor (HGF)/c-met pathway in rats experimentally envenomated with $B$. jararaca venom was reported [119]. Active HGF production is enhanced in response to infectious challenges, but the increase in endogenous HGF levels is transient and insufficient. HGF targets the endothelium and epithelium of various organs to suppress local inflammation, coagulation, and apoptotic death. In various injury and disease models, HGF promotes cell survival, regeneration of tissues, and suppresses and improves chronic inflammation and fibrosis [120]. The direct anti-inflammatory action of HGF in chronic renal disease 
is also likely attributable to the blockade of pro-inflammatory factor nuclear kappa B (NF- $\mathrm{B}$ ) signaling in tubular epithelial cells [121-123].

The refractory complications associated with AKI induced by Bothrops envenoming should be promptly treated with RRT according to the clinical severity. The oliguria and anuria are important causes of hypervolemia, followed by hyperkaliemia in these patients, and it is the most relevant indication of RRT in Bothrops accidents. A recent study reported that the mechanical ventilation, hypotension and capillary leakage are independent risk factors to death in snakebite envenoming [12]. However, in the selected studies in this systematic review, none of them described the type of RRT employed.

Acute kidney injury is asymptomatic in the first stages of KDIGO. Thus, efforts to prevent, rapidly diagnose and to treat the AKI are key clinical priorities $[24,124]$.

\section{Conclusions}

Bothrops venom related acute kidney injury is a common and potentially fatal complication of snakebite envenoming in Latin America. Scarce human studies reported the incidence of AKI and associated risk factors in this scenario. The presence of coagulopathy, such as abnormal aPTT, hypofibrinogenemia and increase of $\mathrm{LDH}$ pointed out the importance of this pathway in the pathogenesis of AKI development. The knowledge about the toxins in Bothrops venom and the experimental isolated renal models are useful tools to explain the clinical picture in humans. The pathogenesis of Bothrops venom related AKI includes immunologic mechanisms, coagulation disorders, pigmenturia, direct nephrotoxicity and the inflammatory response with systemic and renal hemodynamic effects. It is important to rapidly recognize Bothrops venom related AKI to improve treatment and reduce fatal complications. New biomarkers (NGAL and MCP-1) can be useful tools to help in early diagnosis in snakebite patients.

\section{Abbreviations}

AIN: acute interstitial nephritis; AKI: acute kidney injury; AKIN: acute kidney injury network; aPTT: activated partial thromboplastin time; ATN: acute tubular necrosis; Bj-BPP-10c: bioactive-proline-rich decapeptide; BPP: bradykinin-potentiating peptides; CK: creatine kinase or phosphokinase; CKD: chronic kidney disease; CRISP: snake venom cysteine-rich secretory proteins; DIC: disseminated intravascular coagulation; FEK: fractional excretion of potassium; ENa: fractional excretion of sodium; GBM: glomerular basement membrane; GFB: glomerular filtration barrier; GFR: glomerular filtration rate; HGF: hepatocyte growth factor; ICAM: intercellular adhesion molecules; KDIGO: kidney disease improving global outcomes; L-AAOs: L-amino acid oxidases; LDH: lactate dehydrogenase;
MCP-1: monocyte chemoattractant protein-1; MDCK: MadinDarby canine kidney; MESH: Medical Subject Headings; NF$\kappa \mathrm{B}$ : factor nuclear kappa B; NGAL: neutrophil gelatinaseassociated lipocalin; NO: nitric oxide; NOS: Newcastle-Ottawa quality assessment scale; $\mathrm{PLA}_{2} \mathrm{~s}$ : phospholipases $\mathrm{A}_{2}$; RIFLE: risk, injury, failure, loss of kidney function, and end-stage kidney disease; ROS: reactive oxygen species; RRT: renal replacement treatment; RVR: renal vascular resistance; SVMs: snake venom metalloproteinases; SVSPs: snake venom serine proteinases; TMA: thrombotic microangiopathy; V: urine flow; VCAM: vascular cell adhesion molecular-1; VEGF: vascular endothelial growth factor; VICC: venom-induced consumption coagulopathy; WHO: World Health Organization; ZO-1: tight junctional protein.

\section{Acknowledgements}

We would like to give special thanks to the Brazilian agencies Coordination for the Improvement of Higher Education Personnel (CAPES), Cearense Foundation for the Support of Scientific and Technological Development (FUNCAP) and National Council for Scientific and Technological Development (CNPq) for the support of this research. We are also grateful to the Toxicological Assistance Centre of Instituto Doutor Jose Frota Hospital and The University of Sydney for the relevant contributions of the research teams.

\section{Availability of data and materials}

Not applicable.

\section{Funding}

The present research was supported by the Brazilian agencies CAPES, FUNCAP and CNPq by means of research grants provided to PLMMA (n. 88881.133546/2016-01), GBM (n. 837577/2016), GBSJ (n. 301174/2017-2) and EFD (Universal Call n.405963/2016).

\section{Competing interests}

The authors declare that they have no competing interests.

\section{Authors' contributions}

PLMM conceived the study and conducted the selection and interpretation of the data. JHHGLP contributed with design and the selection of the studies. AMCM, NB and EFD revised this paper. GCM and GBSJ performed the design and interpretation of the data and revision. All authors read and approved the final manuscript.

\section{Ethics approval}

Not applicable. 


\section{Consent for publication}

Not applicable.

\section{References}

1. World Health Organization. Neglected tropical diseases [cited 2020 April 26] Available from: https://www.who.int/neglected_diseases/diseases/en/.

2. Kidney Disease Improving Global Outcomes (KDIGO): Clinical practice guideline for acute Kidney Injury. Kidney Int. 2012;2(1):1-138.

3. Hoste EAJ, Kellum JA, Selby NM, Zarbock A, Palevsky PM, Bagshaw SM, et al. Global epidemiology and outcomes of acute kidney injury. Nat Rev Nephrol. 2018;14(10):607-25.

4. Sitprija V. Tropical diseases: a public health problem with impact on nephrology. In: Baliero L, editor. Nefrologia Tropical. 1a ed. Brazil. p. 1-17. 2019.

5. Albuquerque PL, Silva GB Jr, Jacinto CN, Lima JB, Lima CB, Amaral YS, et al. Acute kidney injury after snakebite accident treated in a Brazilian tertiary care centre. Nephrology (Carlton). 2014 Dec;19(12):764-70.

6. Pinho FM, Yu L, Burdmann EA. Snakebite-induced acute kidney injury in Latin America. Semin Nephrol. 2008 Jul 1;28(4):354-62.

7. Mohamed F, Endre ZH, Buckley NA. Role of biomarkers of nephrotoxic acute kidney injury in deliberate poisoning and envenomation in less developed countries. Br J Clin Pharmacol. 2015 Jul;80(1):3-19.

8. Otero R, Gutiérrez J, Beatriz Mesa M, Duque E, Rodríguez O, Luis Arango J, et al. Complications of Bothrops, Porthidium, and Bothriechis snakebites in Colombia. A clinical and epidemiological study of 39 cases attended in a university hospital. Toxicon. 2002 Aug;40(8):1107-14.

9. Milani Júnior R, Jorge MT, de Campos FP, Martins FP, Bousso A, Cardoso JL, et al. Snake bites by the jararacucu (Bothrops jararacussu): clinicopathological studies of 29 proven cases in Sao Paulo State, Brazil. QJM. 1997 May;90(5):323-34.

10. Amaral CFS, da Silva OA, Ribeiro MMF, dos Reis RJ, Carneiro JG, Castro JRS. Insuficiencia renal Aguda secundária a acidentes ofídicos bothrópico e crotálico. Análise de 63 casos. Rev Inst Med Trop São Paulo. 1986 Jul-Ago;28(4):220-7.

11. Vencio D. Estudo do ofidismo em Goias: comprometimento da função renal. Rev Goiana Med. 1988;34:95-116.

12. Priyamvada PS, Jaswanth C, Zachariah B, Haridasan S, Parameswaran $\mathrm{S}$, Swaminathan RP. Prognosis and long-term outcomes of acute kidney injury due to snake envenomation. Clin Kidney J. 2019:1-7.

13. Waiddyanatha S, Silva A, Siribaddana S, Isbister GK. Long-term effects of snake envenoming. Toxins (Basel). 2019 Mar 31;11(4):pii: E193.

14. Albuquerque PLMM, Silva Jr GB, Meneses GC, Martins AMC, Lima $\mathrm{DB}$, Raubenheimer J, et al. Acute kidney injury induced by Bothrops venom: insights into the pathogenic mechanisms. Toxins (Basel). 2019 Mar 5;11(3):pii: E148.

15. Jorge RJ, Jorge AR, de Menezes RR, Mello CP, Lima DB, Silveira JA, et al. Differences between renal effects of venom from two Bothrops jararaca populations from southeastern and southern Brazil. Toxicon. 2017 Jan;125:84-90.

16. Moreira V, Teixeira C, Borges da Silva H, D'Imperio Lima MR, Dos-Santos MC. The role of TLR2 in the acute inflammatory response induced by Bothrops atrox snake venom. Toxicon. 2016 Aug;118:121-8.

17. De Sousa FC, Jorge AR, de Menezes RR, Torres AF, Mello CP, Lima DB, et al. Bothrops erythromelas venom induces apoptosis on renal tubular epithelial cells. Toxicon. 2016 Aug;118:82-5.

18. Marinho AD, Morais IC, Lima DB, Jorge AR, Jorge RJ, Menezes RR, et al. Bothropoides pauloensis venom effects on isolated perfused kidney and cultured renal tubular epithelial cells. Toxicon. 2015 Dec 15;108:126-33.

19. Dantas RT, Jorge AR, Jorge RJ, Menezes RR, Lima DB, Torres AF, et al. I-amino acid oxidase from Bothrops marajoensis causes nephrotoxicity in isolated perfused kidney and cytotoxicity in MDCK renal cells. Toxicon. 2015 Sep 15;104:52-6.
20. Wanderley CW, Silva CM, Wong DV, Ximenes RM, Morelo DF, Cosker $F$, et al. Bothrops jararacussu snake venom-induces a local inflammatory response in a prostanoid- and neutrophil-dependent manner. Toxicon. 2014 Nov;90:134-47.

21. de Morais IC, Torres AF, Pereira GJ, Pereira TP, Pessoa Bezerra de Menezes $\mathrm{RR}$, Mello CP, et al. Bothrops leucurus venom induces nephrotoxicity in the isolated perfused kidney and cultured renal tubular epithelia. Toxicon. 2013 Jan;61:38-46.

22. Carrasco PA, Mattoni Cl, Leynaud GC, Scrocchi GJ. Morphology, phylogeny and taxonomy of South American bothropoid pitvipers (Serpentes, Viperidae). Zool Scr. 2012 Feb 7;41(2):109-24.

23. World Health Organization. Venomous snakes and antivenoms search interface. WHO;2017.

24. Chippaux JP. Incidence and mortality due to snakebite in the Americas. PLoS NegI Trop Dis. 2017 Jun;11(6):e0005662.

25. Jha $\mathrm{V}$, Parameswaran $\mathrm{S}$. Community-acquired acute kidney injury in tropical countries. Nat Rev Nephrol. 2013 May;9(5):278-90.

26. Chugh KS. Snake-bite-induced acute renal failure in India. Kidney Int. 1989 Mar;35(3):891-907.

27. Tianyi FL, Agbor VN, Tochie JN, Kadia BM, Nkwescheu AS. Communitybased audits of snake envenomations in a resource-challenged setting of Cameroon: case series. BMC Res Notes. 2018 May 18;11(1):317.

28. Michael G, Aliyu I, Grema B. Primary prevention of snakebite envenoming in resource-limited settings: A narrative review. Environ Dis. 2019 Jun;4(2).

29. Tochie JN, Temgoua MN, Njim T, Celestin D, Tankeu R, Nkemngu NJ. The neglected burden of snakebites in Cameroon: a review of the epidemiology, management and public health challenges. BMC Res Notes. 2017 Aug 14;10(1):405.

30. Estevao-Costa MI, Gontijo SS, Correia BL, Yarleque A, Vivas-Ruiz D, Rodrigues $\mathrm{E}$, et al. Neutralization of toxicological activities of medicallyrelevant Bothrops snake venoms and relevant toxins by two polyvalent bothropic antivenoms produced in Peru and Brazil. Toxicon. 2016 Nov;122:67-77.

31. Schenberg S. Immunological (Ouchterlony method) identification of intrasubspecies qualitative differences in snake venom composition. Toxicon. 1963 Mar;1(2):67-75.

32. Jiménez-Porras JM. Differentiation between Bothrops nummifer and Bothrops picadoi by means of the biochemical properties of their venoms. In: Press NYP, editor. First International Symposium on Animal Toxins; April 9-11; New Jersey, U.S. p. 307-21. 1966.

33. Jiménez-Porras JM. Intraspecific variations in composition of venom of the jumping viper, Bothrops nummifera. Toxicon. 1964 Dec;2:187-95.

34. Aragón F, Gubensek F. Bothrops asper venom from the Atlantic and Pacific zones of Costa Rica. Toxicon. 1981;19(6):797-805.

35. Moreno E, Alape A, Sánchez M, Gutiérrez JM. A new method for the detection of phospholipase A2 veriants: Identification of isozymes in the venoms of newborn and adult Bothrops asper (terciopelo) snakes. Toxicon. 1988;26(4):363-71.

36. Gene JA, Roy A, Rojas G, Gutiérrez JM, Cerdas L. Comparative study on coagulant, defibrinating, fibrinolytic and fibrinogenolytic activities of Costa Rican Crotaline snake venoms and their neutralization by a polyvalent antivenom. Toxicon. 1989;27(8):841-8.

37. Mandelbaum FR, Serrano SM, Sakurada JK, Rangel HA, Assakura MT. Immunological comparison of hemorrhagic principles present in venoms of the Crotalinae and Viperinae subfamilies. Toxicon. 1989;27(2):169-77.

38. Sousa LF, Nicolau CA, Peixoto PS, Bernardoni JL, Oliveira SS, Portes-Junior JA, et al. Comparison of phylogeny, venom composition and neutralization by antivenom in diverse species of bothrops complex. PLoS Negl Trop Dis. 2013 Sep 12;7(9):e2442.

39. Cardoso KC, Silva MJ, Costa GGL, Torres TT, Del Bem EV, Vidal RO, et al. A transcriptomic analysis of gene expression in the venom gland of the snake Bothrops alternatus (urutu). BMC Genomics. 2010 Oct 26;11:605. 
40. Gutierrez JM, Rucavado A, Escalante T, Diaz C. Hemorrhage induced by snake venom metalloproteinases: biochemical and biophysical mechanisms involved in microvessel damage. Toxicon. 2005 Apr 17;45(8):997-1011.

41. Fernandes CM, Zamuner SR, Zuliani JP, Rucavado A, Gutierrez JM, Teixeira Cde F. Inflammatory effects of $\mathrm{BaP1}$ a metalloproteinase isolated from Bothrops asper snake venom: leukocyte recruitment and release of cytokines. Toxicon. 2006 Apr;47(5):549-59.

42. Schattner M, Fritzen M, Ventura JS, de Albuquerque Modesto JC, Pozner RG, Moura-da-Silva AM, et al. The snake venom metalloproteases berythractivase and jararhagin activate endothelial cells. Biol Chem. 2005 Apr;386(4):369-74.

43. Sitprija $\vee$, Sitprija $S$. Renal effects and injury induced by animal toxins. Toxicon. 2012 Oct;60(5):943-53.

44. Moura-da-Silva AM, Baldo C. Jararhagin, a hemorrhagic snake venom metalloproteinase from Bothrops jararaca. Toxicon. 2012 Sep 1;60(3):280-9.

45. Chisari A, Spinedi E, Voirol MJ, Giovambattista A, Gaillard RC. A phospholipase A2-related snake venom (from Crotalus durissus terrificus) stimulates neuroendocrine and immune functions: determination of different sites of action. Endocrinology. 1998 Feb;139(2):617-25.

46. de Albuquerque Modesto JC, Spencer PJ, Fritzen M, Valenca RC, Oliva ML, da Silva MB, et al. BE-I-PLA2, a novel acidic phospholipase A2 from Bothrops erythromelas venom: isolation, cloning and characterization as potent anti-platelet and inductor of prostaglandin 12 release by endothelial cells. Biochem Pharmacol. 2006 Jul 28;72(3):377-84.

47. Machado Braga MD, Costa Martins AM, Alves CD, de Menezes DB, Martins RD, Ferreira Barbosa PS, et al. Purification and renal effects of phospholipase $A(2)$ isolated from Bothrops insularis venom. Toxicon. 2008 Feb;51(2):181-90.

48. Evangelista IL, Martins AM, Nascimento NR, Havt A, Evangelista JS, de Noroes TB, et al. Renal and cardiovascular effects of Bothrops marajoensis venom and phospholipase A2. Toxicon. 2010 Jun 1;55(6):1061-70.

49. Yu Gui RL, and Morley D. Hollenberg. Bidirectional regulation of renal hemodynamics by activation of PAR1 and PAR2 in isolated perfused rat kidney. Am J Physiol Renal Physiol. 2003 Jul;285(1):95-104.

50. Rossier BC, Stutts MJ. Activation of the epithelial sodium channel (ENaC) by serine proteases. Annu Rev Physiol. 2009;71:361-79.

51. Velez SM, Salazar M, Acosta de Patino H, Gomez L, Rodriguez A, Correa $D$, et al. Geographical variability of the venoms of four populations of Bothrops asper from Panama: Toxicological analysis and neutralization by a polyvalent antivenom. Toxicon. 2017 Jun 15;132:55-61.

52. Laines J, Segura A, Villalta M, Herrera M, Vargas M, Alvarez G, et al. Toxicity of Bothrops sp snake venoms from Ecuador and preclinical assessment of the neutralizing efficacy of a polyspecific antivenom from Costa Rica. Toxicon. 2014 Sep;88:34-7.

53. Slagboom J, Kool J, Harrison RA, Casewell NR. Haemotoxic snake venoms: their functional activity, impact on snakebite victims and pharmaceutical promise. Br J Haematol. 2017 Jun;177(6):947-59.

54. Sant'Ana Malaque CM, Gutiérrez JM. Snakebite Envenomation in Central and South America. 2015 Oct:1-22.

55. David L. Hardy S. Bothrops asper (Viperidae) snakebite and field researchers in middle America. Biotropica. 1994 Jun;26(2):198-207.

56. Polizelli JAKC. Snake bites accidents caused by Bothrops moojeni: report of 37 cases. Rev Inst Med Trop Sao Paulo. 1988;30(6):424-32.

57. Jorge MT, Ribeiro LA, O'Connell JL. Prognostic factors for amputation in the case of envenoming by snakes of the Bothrops genus (Viperidae). Ann Trop Med Parasitol. 1999 Jun;93(4):401-8.

58. Pinho FMO, Burdmann EA. Fatal cerebral hemorrhage and acute renal failure after young Bothrops Jararacussu snake bite. Ren Fail. 2009 Mar;23(2):269-77.

59. Ribeiro LA, Albuquerque MJ, Pires de Campos VAF, Katz G, Takaoka NY, Lebrao ML, et al. [Deaths caused by venomous snakes in the State of São Paulo: evaluation of 43 cases from 1988 to 1993]. Rev Assoc Med Bras. 1998 Oct-Dec;44(4):312-8. [Article in Portuguese].
60. Azevedo-Marques MM, Cupo P, Hering SE. [Chapter IV: Accidents due to Venomous Animals - Venomous Serpents] Capitulo IV: Acidentes por Animais Peconhentos: Serpentes Peconhentas. In: Faculdade de Medicina RP, Sao Paulo, editor. Urgencias e Emergencias Dermatologicas e Toxicologicas. 36. Sao Paulo, Brasil. p. 480-9. 2003.

61. Otero-Patino R. Epidemiological, clinical and therapeutic aspects of Bothrops asper bites. Toxicon. 2009 Dec 1;54(7):998-1011.

62. Franca FOS, Barbaro KCB, Fan HW, Cardoso JLC, Sano-Martins IS, Tomy SC, et al. Theakston and the Butantan Institute Antivenom Study Group. Envenoming by Bothrops jararaca in Brazil: association between venom antigenaemia and severity at admission to hospital. Trans Royal Soc Trop Med Hyg. 2003;97:312-7.

63. Sgrignolli LR, Mendes GEF, Carlos CP, Burdmann EA. Acute kidney injury caused by bothrops snake venom. Nephron Clin Pract. 2011;119(2):c131-6.

64. Lima LCA, Bombarda F, Cortellazze R, Trentin GC, Smolentzov S. Ophidian accident-related multi-organ failure: a case report. Rev Bras Ter Intensiva. 2010;22(4):399-402.

65. Ministério da Saúde - Brasil. Accidents due to venomous animals - Reported cases in System of Diseases of Compulsory Declaration - Brazil [Acidentes por Animais peconhentos - Notificacoes registradas no Sistema de Informacao de Agravos de Notificacao - Brasil]. 2018.

66. Alves EC, Sachett JAG, Sampaio VS, Sousa JDB, Oliveira SS, Nascimento EFD, et al. Predicting acute renal failure in Bothrops snakebite patients in a tertiary reference center, Western Brazilian Amazon. PLoS One. 2018 Aug 17;13(8):e0202361.

67. Queiroz LP, Moritz RD. Acidente botrópico em Florianópolis. Arq Catarinenses Med. 1989;18:163-6.

68. Cupo PAMM, Hering SE, Menezes JB. Acidentes ofídicos: análise de 102 casos. XXI Congresso da Sociedade Brasileira de Medicina Tropical; Sao Paulo, Brazil. p. 23-4. 1985.

69. Kouyoumdjian JAPC, Lobo SMA. Acidentes ofídicos causados por Bothrops moojeni na Região de São José do Rio Preto-SP. Arq Bras Med. 1990;64(64):164-71.

70. Nishioka SA, Silveira PV. A Clinical and Epidemiologic Study of 292 Cases of Lance-Headed Viper bite in a Brazilian Teaching Hospital. Am Soc Trop Med Hyg. 1992 Dec;47(6):805-10.

71. Bucaretchi F, Herrera SRF, Hyslop S, Baracat ECE, Vieira RJ. Snakebites by Bothrops spp in children in Campinas, Sao Paulo, Brazil. Rev Inst Med Trop Sao Paulo. 2001 Nov-Dec;43(6):329-33.

72. Acosta RA, Uzcategui W, Azuaje R, Aguilar I, Girón ME. Análisis clínico y epidemiológico de los accidentes por mordeduras de serpientes del género Bothrops en Venezuela. Rev Cubana Med Trop. 2000 May-Aug;52(2):90-4.

73. Pinto RNL, Souza LCS, Silva AM, Pereira LIA, Andrade JG. Estudo clinicoepidemiologico de 774 casos de acidentes ofidicos. Rev Soc Bras Med Trop. 1987;20(Suppl):56.

74. Aye KP, Thanachartwet V, Soe C, Desakorn V, Thwin KT, Chamnanchanunt $S$, et al. Clinical and laboratory parameters associated with acute kidney injury in patients with snakebite envenomation: a prospective observational study from Myanmar. BMC Nephrol. 2017 Mar 16;18(1):92.

75. Ribeiro LA, Jorge MT. Acidente por Serpentes do Genero Bothrops: serie de 3.139 casos. Rev Soc Bras Med Trop. 1997 Nov-Dec;30(6):475-80.

76. Gutierrez JM, Escalante T, Rucavado A. Experimental pathophysiology of systemic alterations induced by Bothrops asper snake venom. Toxicon. 2009 Dec;54(7):976-87.

77. Fundacao Nacional de Saude. Manual de Diagnostico e Tratamento de Acidentes por Animais Peconhentos. 2a, editor. Brasilia.. p. 37-44. October, 2001.

78. Cruz LS, Vargas R, Lopes AA. Snakebite envenomation and death in the developing world. Ethn Dis. 2009;19(1 Suppl 1):S1-42-6.

79. da Silva OA, Lopes M, Godoy P. Intensive care unit treatment of acute renal failure following snakebite. Am Soc Trop Med Hyg. 1979 Mar;28(2):401-7. 
80. Rezende NA, Amaral CF, Bambirra EA, Lanchat JJ, Coimbra TM. Functional and histopathological renal changes induced in rats by Bothrops jararaca venom. Braz J Med Biol Res. 1989;22(3):407-16.

81. Burdmann EA, Woronik V, Prado EB, Abdulkader RC, Saldanha LB, Barreto $\mathrm{OCO}$, et al. Snakebite-induced acute renal failure: an experimental model. Amn Soc Trop Med Hyg. 1993 Jan;48(1):82-8.

82. Mello SM, Linardi A, Renno AL, Tarsitano CA, Pereira EM, Hyslop S. Renal kinetics of Bothrops alternatus (Urutu) snake venom in rats. Toxicon. 2010 Feb-Mar;55(2-3):470-80.

83. Rocha ML, Valenca RC, Maia MB, Guarnieri MC, Araujo IC, Araujo DA Pharmacokinetics of the venom of Bothrops erythromelas labeled with 131 I in mice. Toxicon. 2008 Sep 1;52(3):526-9.

84. Serra H, Monteiro A, Fonteles MC. The effect of Bothrops jararaca venom on rat kidney after short-term exposure: preliminary results. Pharmacol Toxicol. 1999 Oct;85:198-200.

85. Barbosa PSF, Faco PEG, Sousa TM, Bezerra ISAM, Fonteles MC, Toyama $\mathrm{MHT}$, et al. Renal toxicity of Bothrops moojeni snake venom and its main myotoxins. Toxicon. 2002 Oct;40(10):1427-35.

86. Martins AM, Sousa FC, Barbosa PS, Toyama MH, Toyama DO, Aprigio CC, et al. Action of anti-bothropic factor isolated from Didelphis marsupialis on renal effects of Bothrops erythromelas venom. Toxicon. 2005 Nov;46(6):595-9.

87. Restrepo-Angulo I, De Vizcaya-Ruiz A, Camacho J. Ion channels in toxicology. J Appl Toxicol. 2010 Aug 24;30(6):497-512.

88. Junqueira-de-Azevedo IL, da Silva MB, Chudzinski-Tavassi AM, Ho PL. Identification and cloning of snake venom vascular endothelial growth factor (svVEGF) from Bothrops erythromelas pitviper. Toxicon. 2004 Oct;44(5):571-5.

89. Guerreiro JR, Lameu C, Oliveira EF, Klitzke CF, Melo RL, Linares E, et al. Argininosuccinate synthetase is a functional target for a snake venom anti-hypertensive peptide: role in arginine and nitric oxide production. J Biol Chem. 2009 Jul 24;284(30):20022-33.

90. Malaque CMS, Duayer IF, Santoro ML. Acute kidney injury induced by thrombotic microangiopathy in two cases of Bothrops envenomation. Clin Toxicol (Phila). 2019 Mar;57(3):213-6.

91. Bucaretchi F, Pimenta MMB, Borrasca-Fernandes CF, Prado CC, Capitan EM, Hyslop S. Thrombotic microangiopathy following Bothrops jararaca snakebite: case report. Clin Toxicol (Phila). 2019 Apr;57(4):294-9.

92. Sitprija V. Snakebite nephropathy. Nephrology (Carlton). 2006;11(5):442-8

93. Havt A, Fonteles MCF, Monteiro HSA. The renal effects of Bothrops jararacussu venom and the role of PLA2 and PAF blockers. Toxicon. 2001 Dec;39(12):1841-6.

94. Boer PA, Gontijo JAR, Cruz-Hofling MA. Bothrops moojeni snake venominduced renal glomeruli changes in rat. Am Soc Trop Med Hyg. 2002 Sep;67(2):217-22.

95. de Castro I, Burdmann EA, Seguro AC, Yu L. Bothrops venom induces direct renal tubular injury: role for lipid peroxidation and prevention by antivenom. Toxicon. 2004 Jun 1;43(7):833-9.

96. Collares-Buzato CB, da Cruz-Hofling MA. Disarray of glomerular and tubular cell adhesion molecules in the course of experimental Bothrops moojeni envenomation. Toxicon. 2014 Feb;78:41-6.

97. Linardi A, Rocha e Silva TA, Miyabara EH, Franco-Penteado CF, Cardoso $\mathrm{KC}$, Boer PA, et al. Histological and functional renal alterations caused by Bothrops alternatus snake venom: expression and activity of $\mathrm{Na}+/ \mathrm{K}+-$ ATPase. Biochim Biophys Acta. 2011 Sep;1810(9):895-906.

98. Pinho FM, Zanetta DM, Burdmann EA. Acute renal failure after Crotalus durissus snakebite: a prospective survey on 100 patients. Kidney Int. 2005 Feb;67(2):659-67.

99. Melo PA, Suarez-Kurtz G. Release of sarcoplasmic enzymes from skeletal muscle by Bothrops jararacussu venom: Antagonism by heparin and by the serum of south American marsupialis. Toxicon. 1988;26(1):87-95.
100. Moura-da-Silva AM, Cardoso DF, Tanizaki MM. Differences in distribution of myotoxic proteins in venoms from different Bothrops Species. Toxicon. 1990;28(11):1293-301.

101. Moreno JA, Martin-Cleary C, Gutierrez E, Toldos O, Blanco-Colio LM, Praga $\mathrm{M}$, et al. AKI associated with macroscopic glomerular hematuria: clinical and pathophysiologic consequences. Clin J Am Soc Nephrol. 2012 Nov;7(1):175-84.

102. Hrovat A, Schoeman JP, de Laat B, Meyer E, Smets P, Goddard A, et al. Evaluation of snake envenomation-induced renal dysfunction in dogs using early urinary biomarkers of nephrotoxicity. Vet J. 2013 Oct;198(1):239-44

103. Gn YM, Ponnusamy A, Thimma V. Snakebite induced thrombotic microangiopathy leading to renal cortical necrosis. Case Rep Nephrol. 2017 Aug 13;2017:1348749.

104. Malaque CMS, Duayer IF, Santoro ML. Acute kidney injury induced by thrombotic microangiopathy in two cases of Bothrops envenomation. Clin Toxicol (Phila). 2019 Mar;57(3):213-6.

105. Bucaretchi F, Pimenta MMB, Borrasca-Fernandes CF, Prado CC, Capitani EM, Hyslop S. Thrombotic microangiopathy following Bothrops jararaca snakebite: case report. Clin Toxicol (Phila). 2019 Apr;57(4):294-9.

106. Maduwage K, Isbister GK. Current treatment for venom-induced consumption coagulopathy resulting from snakebite. PLoS Negl Trop Dis. 2014 Oct;8(10):e3220.

107. Torrez PP, Said R, Quiroga MM, Duarte MR, Franca FO. Forest pit viper (Bothriopsis bilineata bilineata) bite in the Brazilian Amazon with acute kidney injury and persistent thrombocytopenia. Toxicon. 2014 Jul;85:27-30.

108. Noutsos T, Currie BJ, Isbister GK. Snakebite associated thrombotic microangiopathy: a protocol for the systematic review of clinical features, outcomes, and role of interventions. Syst Rev. 2019;8(1):212.

109. Prakash J, Singh VP. Changing picture of renal cortical necrosis in acute kidney injury in developing country. World J Nephrol. 2015 Nov 6;4(5):4806.

110. Edelstein CL. Acute Kidney Injury: Pathogenesis, Diagnosis and Management. In: Schrier RW, editor. Renal and Electrolyte Disorders. 8 ed. China: Wolters Kluwer. p. 325-400. 2018.

111. Gundappa RK, Sud K, Kohli HS, Jha V, Gupta KL, Joshi K, et al. Snakebite induced acute interstitial nephritis: report of a rare entity. Ren Fail. 2009 May;24(3):369-72.

112. V Sitprija, R Suvanpha, C Pochanugool, S Chusil, K Tungsanga. Acute interstitial nephritis in snakebite. Am Soc Trop Med Hyg. 1982 Mar;31(2):408-10

113. Priyamvada PS, Shankar V, Srinivas BH, Rajesh NG, Parameswaran S. Acute interstitial nephritis following snake envenomation: a single-center experience. Wilderness Environ Med. 2016 Jun;27(2):302-6.

114. Golay V, Roychowdhary A, Pandey R, Singh A, Pasari A, Abraham A Acute interstitial nephritis in patients with viperine snake bite: single center experience of a rare presentation. Saudi J Kidney Dis Transpl. 2012 Nov;23(6):1262-7.

115. Danis R, Ozmen S, Celen MK, Akin D, Ayaz C, Yazanel O. Snakebiteinduced acute kidney injury: data from Southeast Anatolia. Ren Fail. 2008;30(1):51-5.

116. Albuquerque PL, Jacinto CN, Silva Junior GB, Lima JB, Veras Mdo S, Daher EF. Acute kidney injury caused by Crotalus and Bothrops snake venom: a review of epidemiology, clinical manifestations and treatment. Rev Inst Med Trop S Paulo. 2013 Sep-Oct;55(5):295-301.

117. Bennett MR, Devarajan P. Proteomic analysis of acute kidney injury: biomarkers to mechanisms. Proteomics Clin Appl. 2011 Feb;5(1-2):67-77.

118. Araujo HP, Lucas EPR, Moura WC, Fatima Barbosa C, Rodrigues RJ, Morais JF, et al. Interlaboratory study for the establishment of Brazilian Bothrops Reference Venom and Antivenom for potency evaluation of Bothrops antivenom. Biologicals. 2017 Sep;49:1-5.

119. Prezoto BC, Kato EE, Goncalves LRC, Sampaio SC, Sano-Martins IS Elevated plasma levels of hepatocyte growth factor in rats experimentally 
envenomated with Bothrops jararaca venom: Role of snake venom metalloproteases. Toxicon. 2019 Apr 15;162:9-14.

120. Nakamura T, Sakai K, Nakamura T, Matsumoto K. Hepatocyte growth factor twenty year on: Much more than a growth factor. J Gastroenterol Hepatol. 2011 Jan;26(Suppl 1):188-202.

121. Gong R, Rifai A, Tolbert EM, Biswas P, Centracchio JN, Dworkin LD. Hepatocyte growth factor ameliorates renal interstitial inflammation in rat remnant kidney by modulating tubular expression of macrophage chemoattractant protein-1 and RANTES. J Am Soc Nephrol. 2004 Nov;15(11):2868-81.

122. da Silva CG, Maccariello ER, Wilson SW, Putheti P, Daniel S, Damrauer $\mathrm{SM}$, et al. Hepatocyte growth factor preferentially activates the anti- inflammatory arm of NF-kappaB signaling to induce A20 and protect renal proximal tubular epithelial cells from inflammation. J Cell Physiol. 2012 Apr;227(4):1382-90

123. Min JK, Lee YM, Kim JH, Kim YM, Kim SW, Lee SY, et al. Hepatocyte growth factor suppresses vascular endothelial growth factor-induced expression of endothelial ICAM-1 and VCAM-1 by inhibiting the nuclear factor-kappaB pathway. Circ Res. 2005 Feb 18;96(3):300-7.

124. Pacheco UP, Zortéa M. Snakebites in southwestern Goiás State, Brazil. J Venom Anim Toxins incl Trop Dis. 2008;14(1):141-51. https://www. scielo.br/scielo.php?script=sci_arttext\&pid=S1678-91992008000100011. 